Copyright (C) 2015 by Academic Publishing House Researcher

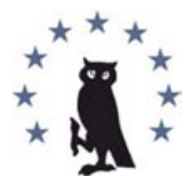

Published in the Russian Federation

European Researcher

Has been issued since 2010.

ISSN 2219-8229

E-ISSN 2224-0136

Vol. 94, Is. 5, pp. 373-380, 2015

DOI: $10.13187 /$ er.2015.94.373

www.erjournal.ru

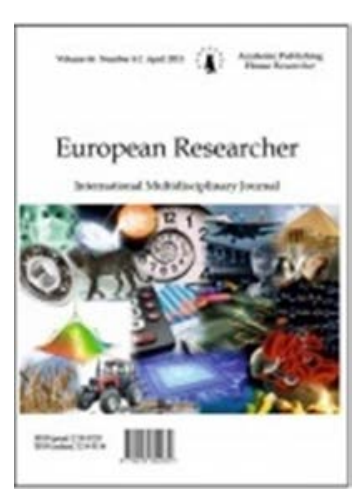

Political sciences

Политические науки

UDC 323

\title{
Nationalistic Trends in Modern Syria
}

1Dilshad Muhammad

2 Filiz Katman

${ }^{1}$ Istanbul Aydin University, Turkey

MA, Political Science and International Relations, Social Sciences Institute

2 Istanbul Aydin University, Turkey

Assist. Prof. Dr., Department of Political Science and International Relations, Faculty of Economics and Administrative Sciences

\begin{abstract}
This article explores dynamics behind the emergence of different nationalistic currents that dominated the modern Syrian political scene. By "modern", here, it is meant the period between 1846, when the term "Syria" was, for the first time, officially associated with a specific territory, and 2000 when Syria's "fierce", not strong, ruler Hafez al-Asad died. As such, the article covers multiple periods as one continuous period. Arab Nationalism, which defeated other currents like Pan Syrianism and Communism, comes on the top of these currents. The article also shows how partisan, clan and/ or family interests led to the utilization of various nationalist thoughts in this regard.
\end{abstract}

Keywords: Syria, Pan-Syrianism, Arab Nationalism.

\section{Introduction}

The rise of nationalism in Europe during the $18^{\text {th }}$ and the $19^{\text {th }}$ centuries did not remain limited to the European contexts. Since early $20^{\text {th }}$ century, nationalism, in its modern sense, gradually appeared in the Middle East. World War I conditions and the dissolution of the Ottoman Empire stimulated this appearance as well. In such a context, the subject of this article is studying nationalism in the Syrian case. The article, more precisely, focuses on Pan Syrianism and Arab Nationalism in Syria. 
The aim of the article is to answer its research question of "Has Arab Nationalism been the only nationalist current in Syria?" To achieve this aim, the article starts by looking for what Syria refers to. The article goes on by elaborating colonial contexts like the French Mandate in Syria where early modern politicization of Syrian society/ societies took place. In the following section, the article directly sheds light on Pan Syrianism and Arab Nationalism and how these two nationalisms evolved. Next, and as the country gains its independence in 1946, the article continues tracing nationalism and its relation with Syrian governments and features how Arab Nationalism became the ruling nationalist trend in Syria.

As a result, the article shows that Pan Syrianism was a territory-based nationalism and emerged due internal dynamics while Arab Nationalism was an ethnic one and was a part of a wider version of nationalism. Another result shows that Pan Syrianism started to decline before, and shortly after, Syria's. The formation of the United Arab Republic in 1956 enabled Pan Arab Nationalist Al Baath Party came to the power.

As for the methodology of the article, primary resources like maps and manuscripts by political parties and/or their leaders have been studied. Hence, the method used in this article is content analysis method. This method has been chosen as the analysis of some original texts, primarily written in Arabic, was essential in conducting the study in the framework of this article. On the secondary resources level, works of prominent scholars who mainly or partly touched on Syrian politics in general have been reviewed. The article also makes references to some scholars of nationalism and state who studied the notion theoretically. The literature review conducted for the article covered academic books and peer viewed journal articles. In this regard, Daniel Pipes' Greater Syria : The History of an Ambition is considered an indispensable book for students of Pan Syrianism. Philip S. Khoury's Syria and the French Mandate: The Politics of Arab Nationalism, 1920-1945 gives an excellent elaboration on the rise of Arab Nationalism in the preindependence era in Syria. As such, methodology applied throughout the article is qualitative as the article analyzes original texts as well as the literature written on the topic.

\section{Terminology}

There is no consensus on how the term "Syria" exactly appeared. Yet there are concrete references that it is a Greek term. According to Lamia R. Shehadeh, "Syria" was coined by the Greeks who derived it from the name "Assyria" and it was used in late $6^{\text {th }}$ century BC (Shehadeh, 2011: 18, 25) (Pipes, 1990: 13). Other possible etymological origins of "Syria" are, according to Shehadeh, the Cuneiform Suri, the Ugaritics sryn and Hebrew Siryon. (Shehadeh, 2011: 18).

Syria was named by its different conquerors according to their vantage point; Ebernari (Beyond the River) by Persians, Al-Sham (To the Left) by Arabs and Outremer (Beyond the Sea) by Crusaders (Shehadeh, 2011: 26). In all cases, the term was loosely referring to parts of Eastern Mediterranean. The first time the term Syria was officially associated with a territory was under the Ottoman Vilayets System of 1846 (Choueiri, 1989: 26) (Celik, 2013: 706). According to an Ottoman map printed in 1893, "Syria" was covering both Vilayet of al-Sham (Damascus) and the Mutasarrifate of al-Quds (J erusalem). Syria became a State under the French Mandate and became a sovereign state since 1946. 


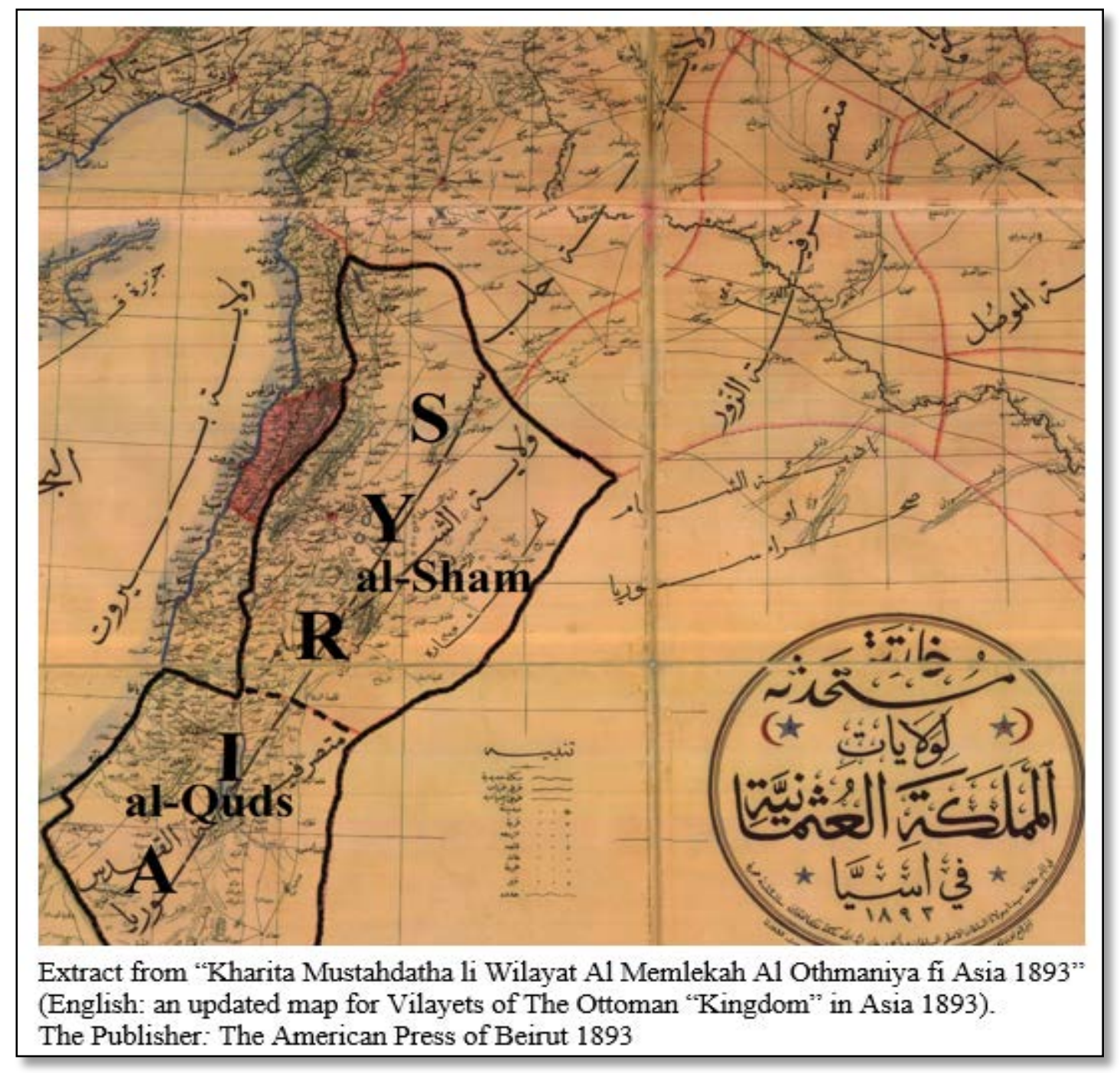

\section{Colonialism and the French Mandate}

For strategic military and economic reasons, European imperial powers were increasingly interested in the Middle Eastern regions during the nineteenth century. According to Dietmar Rothermund (2006), Europeans "wanted to advance their economic interests. [And] the opening of Suez Canal in 1869 was an important event in this context. The Canal literarily cuts across the Ottoman Empire and facilitated the spread of European colonialism" (Rothermund, 2006: 102).

As a colonial rival to the Kingdom of Great Britain, which managed to increase its presences in Egypt, the way to its important colony of India, the French Empire, to counterbalance this presence, started to seek a foothold in the region. This rivalry however, did not cause a conflict between the British and the French but rather, it resulted in a broad multi-level understanding. This had taken a form of signing many agreements like The Sykes-Picot Agreement of 1916, San Remo Conference of April 1920 and The Treaty of Sevres of August 1920. In May 1916, The British represents by Mark Sykes and The French represented by François Georges-Picot signed the Asia Minor Agreement, which is also better known as Sykes-Picot Agreement (1). Basing on these political deals, European colonial powers divided the post-Ottoman East Mediterranean region into many territories. The British and The French managed to have the ultimate leverage over the region. By setting borders by those colonial powers, these territories will later on be transformed into states in a decolonization process.

Simultaneously with signs of dissolution of the Ottoman Empire in early twentieth century, Syria, which was under the control of this empire, became a focal point for The French Republic (2). Although it had been Status quo before, France has legally reinforced its ultimate leverage over 
Syria by an official recognition by the League of Nations of its presence in Syria in 1922. The French control over Syria was labeled as Mandate, through which The League of Nations, without setting a timetable, asked the French authorities to "facilitate the progressive development of Syria [and Lebanon] as independent state[s]" (Yapp, 1996: 86).

Throughout the period of the Mandate in Syria, French authorities adopted sectarian-based measures on a large scale. Mandate authorities were keen in dealing with Syria's different religious, ethnic and tribal components as separate sovereign entities and these authorities had set their policies accordingly. The classical colonial approach of divide and rule became the major attribute of The French Mandate. In the Syrian case, this approach has explicitly had its roots in the French claims of protecting minorities in general and Christians in particular (Khoury, 1987: 5). One of the major first steps the Mandate authorities have taken was to divide, where applicable, the Syrian territory into many statelets (3). Along with The State of Greater Lebanon and The State of Hatay, The State of Syria (including Damascus and Aleppo), The Alawite State and The State of J abal Druze were created (Provence, 2005: 50). Each of these statelets had its own territory and its own flag. They have been easily created because each statelet's territory was overwhelmingly populated by one homogenous [religious] community. Moreover, other minorities who had not been granted a state like Christians, Kurds, Circassians and Bedouin tribes were still treated on their ethnic and/or religious identities by the French Mandate authorities. All those minorities were usually represented by their religious, ethnic and tribal leaders like clergymen and sheikhs. This kind of representation was promoted by both parties: minority leaders and Mandate authorities. Local leaders were taking advantages of this situation to consolidate their leadership over their groups and the French authorities were maintaining a continuity of a deep sectarian division among the Syrian societies. For example, the French policies prevented the Syrian "Christians who were not hostile to [Syrian patriotic] nationalism" to be integrated in the political life. (White, 2011: 56).

The roots of such a kind of representation can be traced back to the Ottoman Millet System (4). Mandate authorities and Christian clergymen preferred to continue a Millet-like system as a way of dealing with each other. That was because the Millet System granted the clergymen not only a religious leadership on behalf of their minorities but also political advantage as they were the sole representatives of their groups (White, 2011: 55-56). It is important here to mention that the local Syrian political power, under the foreign mandate, was not totally restricted in the hands of religious, ethnic and tribal leaders. Other individuals like merchants and urban notables played significant role in the politics of that time. This trend was, however, much more popular among Sunni Arabs. And this can be attributed to different reasons. First, Sunni Arabs were not a minority, both ethnically and religiously, hence their politics could not be easily manipulated as it happened inside other minorities. Second, they inhabited in relatively vast geographical space, the fact that did not facilitate building an inner sect-based central stronghold. Third, which is related to the previous reason and is the most important, is the fact that Syria's most important cities at that time were locating in the geographical space largely inhabited by Sunnis. The last factor, however, does not necessarily entail that people from other minorities were not inhabited in the Syria cities.

\section{The Birth of Nationalisms in Syria}

Early nationalist thoughts in Syria started to appear in the Syrian cities by the late of $19^{\text {th }}$ century and the beginning of the $20^{\text {th }}$ century. These thoughts were probably affected by a series of political developments throughout the world. As Anthony D. Smith (2010: 7) states that nationalism does not appear by armed struggle but rather but cultural and intellectual evidences, nationalist sentiments in Syria were articulated by intellectuals like thinkers and writers (5). Those thinkers according to many scholars were influenced, in their turn, by notions of nation-state and nationalism in Europe, which, as mentioned before, were results of modernization (Farah, 1963: 144). In addition to the European factor, the rise of Turkish nationalism during the very last period of The Ottoman Empire (and Kemalism in The Republic of Turkey), was another crucial developments in this regard (6). Eventually, the notion of nationalism in Syria was developed into two directions: Pan Syrianism and Arab Nationalism. However, both of them fell victim to the mandate" and process of de-colonialization as the created Syrian state was not fulfilling their political ambitions (Gelvin, 2011: 215). Nevertheless, Arab nationalism remained the most powerful nationalism in the Syrian political scene since then (7). 


\section{A) Pan Syrianism}

Aspects of modernization in The Ottoman Empire like the Tanzimat decrees, new market conditions, standardizing institutions and attempting to set norms for the public and private domains increased communication between (citizens) of The Ottoman Empire. Transportation and modern technologies further eased this communication and made many social groups to develop social, economic and cultural ties. These ties created a shared social, economic and cultural "spaces". Such spaces, in some case, contributed in forming regions like The Greater Syria (Gelvin 2011: 211) (8). According to the most influential thinker and politician of Pan Syrianism Antun Saadah, Syrians are a complete nation and they are not part of larger nations [Arabs] (Pipes 1990: 41) (9). Greater Syria gradually became a "distinct economic unit" and "a British-built telegraph connected Aleppo, Beirut and Damascus" (Gelvin 2011: 211).

Taking into consideration Benedict Anderson (2006: 145) and Karl W. Deutsch's (Smith, 1954: 47) focus on the importance of communication in shaping and making nations and J ames L. Gelvin's previous communicational account, the Greater Syria witnessed the emergence of what is called Pan Syrianism as a nationalism of that region. Pan Syrianism is a political ideology that sees that the region of the Greater Syria has a nation; Syrians (10). Pan-Syrianism started to flourish by the early twentieth century (Pipes, 1990: 3). This version of nationalism was concerned not with an ethnicity or religious but with a geographical zone so to speak. According to Pan-Syrianists, people of the Greater Syria are eligible to be a nation. This version of nationalism did not identify itself with Arab nationalism (Pipes, 1990: 41). The key ideological and organizational leader of this nationalism was the Christian Lebanese Antun Saadah, the founder of Syrian Social Nationalist Party, SSPN.

\section{B) Arab Nationalism}

Another and the more powerful, version of nationalism dominated the region of Syria since the late $19^{\text {th }}$ century, was Arab Nationalism. The political conditions of World War I in general and the Ottoman Empire conditions in particular, had encouraged the Arabs to act nationalistically. Pushed by the British and led by Hussein bin Ali (1854-1931), Arabs revolted against the Ottoman rule in 1916 (11). While being led by an Arab from Hijaz (today a part of Saudi Arabia), The Arab Revolt, to a great extent, took place in today's Syria and other neighboring countries. Bin Ali's offspring like King Faysal settled in Damascus and was politically active there. These actions in Damascus highly contributed in the spread of Arab Nationalism in Syria. After the independence in 1946 and until the union with Egypt in 1958, Syria witnessed political disorder; series of military coups were carried out. The first coup took place in March 1949 and a shift happened in the Syrian politics; the traditional elite was somehow pushed aside and "the tables [were] turned on" it (Chaitani, 2007: 127) (12). Since then and until 1958, the political power in Syria was in ebb and flow movement between traditional elites, Pan-Syrianists, Communists and Arab Nationalists, and all struggled to rule the country.

\section{Syria's Independence}

The last French soldier left Syria on 17 April 1946 and from that date The Republic of Syria was born. Military juntas ruled Syria from March 1949 to February 1954. Since then and until the unity with Egypt in 1958, Syria witnessed democratic parliamentary rule especially by introducing the secret ballots system as a new electoral technique (Krokowska, 2011: 85).

Arab nationalists succeeded to overcome their political opponents. Benefiting from the high popularity of Arab nationalism at that time in other Arab countries, The Arab Socialist Baath Party in Syria, with its Arab Nationalism ideology, managed to become the main political player in Syria. At that time, the Arab nationalist Egyptian president Gamal Abd al-Nasser (1918-1970) was the most popular Arab leader and "no other Arab leader approached his status" (Cleveland \& Bunton, 2013: 291). To overcome its main rival (the Syrian Communist Party, SCP), The Baath Party "approached Nasser about a union" (Cleveland \& Bunton, 2013: 304). As a result, Egypt and Syria were unified in February 1958 under The United Arab Republic, UAR which broke up in 1961. During the period of The UAR, dramatic shifts in Syrian politics continued. Fundamentally dominated by Egypt (Cleveland \& Bunton, 2013: 304), UAR has excluded lots Syrian political movements. Minorities for example, "nearly disappeared from the four Syrian cabinets of the UAR years" (Pipes, 1990: 155). 
After the collapse of UAR, the Baath Party regained the rule in 1963 by a military coup carried out by Hafez al-Asad (1930-2000) and other Baathist military officers. Al-Asad however, conducted an inner coup in his own ruling party in 1970 and seized the rule alone since that time. After the last coup, Syrian politics again dramatically shifted and entered into a different era. AlAsad has crucially destroyed the urban Sunni elites, who were big landowners at the same time, by promoting land and property reforms (Pipes, 1990: 178). It can be argued here that al-Asad as coming from a rural background, promoted agricultural and land-owning reforms in the interest of his Alawite sect which its majority was villagers. This however was not the case for other Syrian rural communities. William L. Cleveland and Martin P. Bunton state that "the majority of Syrian peasants remained landless" as a result of these reforms (Cleveland \& Bunton, 2013: 419). Since 1970 and on, Al-Asad has strengthened his rule by posing his Alawite and family figures in important state institutions. The state under his control was "stifling, inefficient and oppressive" (Cleveland \& Bunton, 2013: 420). These policies contributed to the inflaming of "the traditional sectarian conflict" as Philip S. Khoury puts it (Khoury, 1987: 5).

According to Nazih N. Ayubi, a strong state should not be hostile to its society. For Ayubi, the Syrian state under al-Asad rule, has never been "strong state" but rather it was a "fierce state" (Ayubi, 2006: 447-450). Elaborating on Ayubi's argument, Toby Dodge says that the Arab state [like Syria] although was "fierce" yet it "lacked the institutional power and political legitimacy to implement government policy effectively. State intervention in society was often unwelcome; regarded by the population at best to be a necessary evil and at worst as an illegitimate intrusion" (Dodge, 2012: 7). That is, although seeming immune against any risk, the Syrian state was fragile from inside and was ready to collapse and fall apart.

\section{Conclusion}

As a political notion, nationalism has extensively been studied by many sociology, anthropology and history scholars on theoretical bases. Numerous works on nationalism in the framework of theory and/ or European case studies have been published. Apart from the domain of Arab Nationalism, as a single entity, only few works have been dedicated to the study of nationalism in Syria. Nationalism in Syria should not only be dealt with as a part of Arab Nationalism or as a modified Arab Nationalism; in fact, nationalism in Syria used to be much more diverse and complex.

Syria used to have two main trends of nationalisms; Pan Syrianism and Arab Nationalism. While the Pan Syrianist thought emerged due to territorial conditions, Arab Nationalism was highly stimulated by external dynamics like the World War I and the collapse of The Ottoman Empire. Benefiting from the momentum of Arab Nationalist thoughts in 1950s, The Baath Party eliminated all its rival and managed to seize the power in Syria since 1963. Under the Baathist Hafez al-Asad rule, Arab Nationalism became a mere façade that cover al-Asad family authoritarian rule. It is important here to notice that not a specific version of nationalism, but rather the nondemocratic way of governing and state management led to such an authoritarianism.

\section{Notes}

1) The Sykes-Picot Agreement has been signed secretly. After the fall of the Tsar of Russia, whom his government partially involved in the agreement, the Bolsheviks exposed the version of the agreement which they have found in the Russian archive. The first reference in English to the Sykes-Picot agreement, was by The Manchester Guardian 26 November 1917. See $<\mathrm{http} / /$ goo.gl/ uoYN2W>

2) From 1852 to 1870 France's official name was The [Second] French Empire. From 18701940 it was called The French [Third] Republic.

3) At early twentieth century, Syria was a common name for today's Syrian Arab Republic, State of Lebanon and Turkey's province of Hatay.

4) "Millet" is a Turkish term meaning "community" or simply "people". Ottoman Millets used to be used to refer to non-Muslim minorities who lived in the Ottoman Empire.

5) This was the case for both Pan Syrianism and Arab Nationalism (Shlaim, 2003) (Groiss 2011: 41-44) (Hajjar 2011: 182). 
6) As far as Arab Nationalism is concerned, another factor can be added here; colonial powers, especially The Great Britain had an influential role in provoking Arab nationslim against The Ottoman rule. See note 11.

7) According to Daniel Pipes, Pan Syrianism was not successful because, as being a secularist and led by Christians, it failed to attract Sunni Muslims who form the majority of Syrian people (Pipes 1990: 43).

8) Greater Syria is a geographical term that refers to today's Syria, Lebanon, J ordan, Israel and Palestinian Territories. It also contains Sanjak of Alexandretta (Hatay Province in The Republic of Turkey).

9) Antun Saadeh was born in 1904 and executed by the Lebanese authorities in 1949. "Syria for Syrians and Syrians are a complete nation" is the first concepts in Explanations of Principles of The Syrian Social Nationalist Party written by Saadeh him self

10) Some argue that Pan-Syrianism used to be headed by Christian figure like Butrus alBustani and Saadeh. They argue that Pan Syrianism was promoted by Christians to prevent Sunni Arabs and their nationalism (Arab Nationalism) to dominate the Syrian political scene (Pipes, 1990: 41-42).

11) Henry McMahon, British High Commissioner in Egypt had promised Hussein bin Ali, the leader of The Arab Revolt (1914-1916) that the British will support the Arab independence from the Ottoman Empire. This was done through a series of letters between the two parts known as McMahon- Hussein Correspondence.

12) The military coup has been conducted by Husni al-Zaim on 30 March 1949. Some arguments relate this coup, among other reasons, to the American role in TAPLINE Project (The Trans-Arabian Pipeline) of 1946. This was a pipeline intended to carry oil from the Arabian American Oil Company, Aramco in Saudi Arabia to the Mediterranean cost of Lebanon passing through J ordan and Syria. Youssef Chaitani states that "the Syrians [on the contrary to Americans] were not enthusiastic" to the project and made many excuses to avoid signing the Pipeline Convention (Chaitani, 2007: 74). Al-Zaim, however, after seizing the power, has swiftly ratified the TAPLINE project (Chaitani, 2007: 132).

\section{References:}

1. Ayubi, N 2006, Over-Stating the Arab State: Politics and Society in the Middle East, I. B. Tauris, London.

2. Celik, K 2013, "The End of 19. Century and the Beginning of the 20. Century Foreign Trade in Syria", J ournal of History School (J OHS), no. XVI, pp.705- 38.

3. Chaitani, Y 2007, Post-Colonial Syria and Lebanon: The Decline of Arab Nationalism and the Triumph of the State, I. B. Tauris.

4. Choueiri, Y 1989, Arab History and the Nation-State: A Study in Modern Arab Histography 1820-1980, Routledge.

5. Cleveland, W \&Bunton, M 2013, a History of the Modern Middle East, Westview Press.

6. Dodge, T 2012, from the "Arab Awakening" to the Arab Spring; the Post-Colonial State

in the Middle East, London School of Economics, (28 April 2015 http:// www.lse.ac.uk/IDEAS/ publications/reports/pdf/SR011/FINAL_LSE_IDEAS__fromTheAr abAwakeningToTheArabSpring_Dodge.pdf).

7. Farah, C 1963, "The Dilemma of Arab Nationalism", Die Welt Des Islams, New Series vol. 8 , no. 3 pp. $140-64$.

8. Gelvin, J 2011, The Modern Middle East: A History, 3rd edn, Oxford University Press.

9. Groiss, A 2011, "Communalism as a Factor in the Rise of the Syria Idea in the 1800s and the Early 1900s", In The Origins of Syrian Nationhood: Histories, Pioneers and Identity, edited by Adel Beshara, Routledge, pp. 30- 54.

10. Hajjar, N 2011, "Between Patriotism and Nationalism: Ameen Rihani's Vision for Lebanon and Syria", In the Origins of Syrian Nationhood: Histories, Pioneers and Identity, Routledge, pp. 163- 89.

11. Khoury, P 1987, Syria and the French Mandate: The Politics of Arab Nationalism 19201945, Princeton University Press.

12. Krokowska, K 2011, "The Fall of Democracy in Syria”, Perceptions vol. XVI, no. 2. pp. 81-98. 
13. Pipes, D 1990, Greater Syria : The History of an Ambition, Oxford University Press.

14. Provence, M 2005, the Great Syrian Revolt and the Rise of Arab Nationalism, University of Texas Press.

15. Rothermund, D 2006, the Routledge Companion to Decolonization, Routledge.

16. Saadeh, A, Explanations of Principles of the Syrian Social Nationalist Party, (12 May 2015), <http:// www.ssnp.com/ new/ library/ saadeh/ principles/

17. Shehadeh, L 2011, "The Name of Syria in Ancient and Modern Usage", In The Origins of Syrian Nationhood: Histories, Pioneers and Identity, edited by Adel Beshara, Routledge, pp. 17- 29.

18. Shlaim, A 2003, "Review: Arab Nationalism in the 20th Century by Adeed Dawisha", The Guardian, viewed 28 April 2015, http://www.theguardian.com/books/2003 /mar/29 / featuresreviews.guardianreview>.

19. Smith, A 2010, Nationalism. 2nd edn, Polity Press.

20. White, B 2011, the Emergence of Minorities in the Middle East: The Politics of Community in French Mandate Syria, Edinburgh University Press.

21. Yapp, M 1996, the Near East since the First World War: A History to 1995, Pearson, New York. 